\title{
Yield Reductions of Wheat Cultivar Obora (UTIQUE96/FLAG-1) due to Russian Wheat Aphid (Diuraphis noxia) Infestation under Field Conditions at Selected Districts of West Showa Zone, Ethiopia
}

\author{
Nahil Abebe ${ }^{1}$ Mulugeta Negeri ${ }^{2}$, Emana Getu ${ }^{3}$, Thangavel Selvara ${ }^{4}$
}

10.18805/ag.D-366

\begin{abstract}
Background: Wheat (Triticum aestivum L.) is an important cereal crop as being consumed as staple food in the world as well as in Ethiopia. The production of wheat in Ethiopia decreased due to the incidence of insect pests. Out of insects' pests the Russian wheat aphid (Diuraphis noxia) is the recent one that causes yield loss either directly or indirectly.

Methods: The experiment was carried out at selected districts of West Showa zone, Ethiopia during off cropping season 2019 to evaluate the yield reduction in wheat crop due to the invasion of Russian wheat aphids. Malamar, Dimethoate, neem seeds, leaves, Beaveria bassiana and Metarhizium anisopliae were used in form of spray.

Result: However, Malamar and Dimethoate highly significantly lowered the population of Diuraphis noxia. The combination of Beaveria bassiana and Metarhizium anisopleae significantly lowered the population of Russian wheat aphid. The combination of Neem leaf and Neem seeds, as well as Beaveria bassiana, proved to be effective against Russian wheat aphid yet they were protected and sound against the environments. Malamar showed the maximum decrease in Diuraphis noxia populations followed by Dimethoate, the combination of Beaveria bassiana and Metarhizium anisopleae.
\end{abstract}

Key words: Beaveria bassiana, Diuraphis noxia, Metarhizium anisopliae, Yield loss.

\section{INTRODUCTION}

Wheat (Triticum aestivum L.) is an important cereal crop as being consumed for staple food in the world (Khan et al. 2000). There is a continuous need of obtaining higher yield to feed a growing population of the world (Khakwani et al. 2012). It is a positioned next amongst the majority key cereal crops in the world, rice and traded globally (FAO, 2009; Najafi, 2014; Falola et al. 2017). The magnitude of wheat fabrication in the globe financial system is confirmed by cultivation of $15 \%$ from 1500 million hectares arable land in the world (Kiss, 2011). Wheat improvement and consumption are grown rapidly as a result of income growth and rapid urbanization in Sub-Saharan Africa (produce 30\% of their domestic requirements) (Sultan, 2016). Ethiopia is the second-largest wheat producers in Sub-Saharan Africa next to South Africa, with a potential expansion to 1.3 million hectares (Nigussie et al. 2015; Haregewoin et al. 2018).

In Ethiopia, wheat is one of the majorities of cereal crops in terms of the area of land allocated (1.6 million hectares), with a production of 3.9 million tonsand many farmers occupied in its production (4.7 million farmers) utilizing productivity of 2.4tone per hectare (CSA, 2014; ATA, 2014). The highlands of the central, south-eastern and northwest parts of the country are the key wheat-growing areas of; and regionally, wheat production comes from Oromia (57.4\%), Amhara (27\%), SNNP (8.7\%) and Tigray (6.2\%) of the nationwide production (CSA, 2014). But nearly all wheat, except few governments, owned large-scale (state) farms and commercial farms produced wheat in the country, is
${ }^{1}$ Department of Plant Science, College of Agriculture, Oda Bultum University, Ciro, Ethiopia.

${ }^{2}$ Department of Plant Science, College of Agriculture and Veterinary Sciences, Ambo University, Ambo, Ethiopia.

${ }^{3}$ Department of Zoological Science, College of Natural and Computational Sciences, Addis Ababa University, Addis Ababa, Ethiopia.

${ }^{4}$ Department of Plant Science, College of Agriculture and Veterinary Sciences, Ambo University, Ambo, Ethiopia.

Corresponding Author: Nahil Abebe, Department of Plant Science, College of Agriculture, Oda Bultum University, Ciro, Ethiopia. Email: nahilan2009@gmail.com

How to cite this article: Abebe, N., Negeri, M., Getu, E. and Selvara, T. (2022). Yield Reductions of Wheat Cultivar Obora (UTIQUE96/FLAG-1) due to Russian Wheat Aphid (Diuraphis noxia) Infestation under Field Conditions at Selected Districts of West Showa Zone, Ethiopia. Agricultural Science Digest. DOI: 10.18805/ ag.D-366.

Submitted: 02-06-2021 Accepted: 08-12-2021 Online: 16-01-2022

produced under rain-fed conditions mostly by small level farmers (Demeke and Di Marcantonio, 2013). The production of wheat in Ethiopia decreased due to few abiotic and biotic stress like the incidence of insect pests and diseases. Out of those, insects' pests the Russian wheat aphid (RWA) Diuraphis noxia Mord is the recent one that causes yield losses either directly or indirectly (Alsam et al. 2005).

Reduced yield of wheat per hectare in Ethiopia is due to conventional techniques of farming, varieties, lack of 
irrigation services, soil productivity and occurance of insect pests and diseases. Even though a lot of insect pests infests wheat (Triticum aestivum L.) in Ethiopia, aphids are the major concerned. Aphids cause yield reductions by sucking the sap of the plants also indirectly $(20-80 \%)$ by transmitting viral and fungal diseases (Alsam et al. 2005). The aphid population depends on the abiotic factors (Aheer et al. 2007/ 2008, Wains, et al. 2008). During spring (February-March) aphid population increases, at the same time biocontrol agents like coccinellids exert a natural check on this pest (Khan et al. 2011). Wheat yield loss due to RWA damage in Ethiopia was estimated to be $70 \%$ (Miller and Haile, 1988); conside years of rainfall shortage, which favors the development of the pest population (Kinelskaya, 2010). it is the major reason for the low yield of wheat is the damage by RWA (Alemu et al. 2012). Russian Wheat Aphids (RWA) is a significant pest problem in many areas in the world (Anna-Maria et al. 2003). This pest has a global distribution the Middle East, USA, South Africa and Ethiopia (Burnett et al.1991). The invasion causes severe deformation of vegetations and inflorescence and be able to considerably reduce the yield due to feeding. The reduction in the yield in the wheat crop is more than out of few a biotic factors like, conventional techniques of farming, reduce yielding varieties, somewhat low stage of soil productiveness and a higher occurrence of insect pests and diseases. The work was carried out to estimate the yield reduction in wheat crop due to the invasion of Russian wheat aphids. Their management to increase the wheat production.

\section{MATERIALS AND METHODS}

The experiment was carried out at selected districts of West Showa zone, Ethiopia during off cropping season 2019 to observe yield reduction in wheat crop infested by Russian wheat aphid. The information of Russian wheat aphids and its yield reduction were recorded throughout the entire trial time (from the third week of January 2019 to the second week of April 2019). The bread wheat Obora(UTIQUE96/ FLAG-1) obtained from Holleta Research Center was used as a cultivar. The crop was sown in rows on the $15^{\text {th }}$ of January, 2019. The treatments were distributed in 27plots; measuring $4.5 \mathrm{~m}^{2}$. The trial was replicated thrice in RCBD. Nine wheat plants from each plot were randomly selected and the number of aphids per tiller of every plant was counted. Yield was recorded from both sprayed and unsprayed plots to evaluate yield reduction. 1000 grains of each plot were calculated and their weights were compered. The abiotic factors $\left(\mathrm{RH} \%\right.$ and ${ }^{\circ} \mathrm{C}$ ) were recorded from an observatory of the field. ANOVA was used to compare the yield reduction and thousand-grain weight reduced, after counting proportion yield reduction (LSD $\mathrm{P} \leq 0.05$ ) using Statistically Analysis Software (SAS, 2000) or Minitab16.1 software as well as IBM, SPSS 20 package was used for statistical analyses. The means were compared through DMRTat $5 \%$ level. Yield loss percentage was calculated by comparing the Weight of treated grain yield with untreated treatments.
The yield reduction percentages were calculated by using the following formulas:

Yield loss $(\%)=$

Protected treatment - unprotected treatment Protected treatment

\section{RESULTS AND DISCUSSION}

The primary detection of aphids on the crop was recorded on $12^{\text {th }}$ of February 2019 (Table 1); (1.82 aphid/plant), afterward a slowly boost in the population were observed that attaining peck in the $3^{\text {rd }}$ week of March 2019 (14.35 aphid/plant). After the $4^{\text {th }}$ week of March, the population started dwindling down 11.25 aphid/plant afterwards, during the $2^{\text {nd }}$ week of April onwards no aphids were seen in the fields. The aphid invasion was concentrated on leaves, spikes and during the mid of March also seen on the stem too.

Effects of temperature and moisture on population dynamics of aphids

Aphid invasion happening during in $2^{\text {nd }}$ week of February on the foliage. At this time, the moisture was $34.2 \%$ and temperature fluctuated between $27.4^{\circ} \mathrm{C}$ to $11.1^{\circ} \mathrm{C}$. At the end of February, the population were slowly declining at the same time as a slight variation in the moisture and temperature were recorded. The declining aphid population maintained the $3^{\text {rd }}$ week of March till the 1 st week of April (Table 1). At this time, $45 \%$ moisture; $27.1^{\circ} \mathrm{C}$ temperature and $11.9^{\circ} \mathrm{C}$ temperature were recorded. Subsequently, the aphid population started declining in the $1^{\text {st }}$ week of April 2019, $(2.96$ aphids/plant) was recorded (Table 1). Throughout April, the $\mathrm{RH}$ ranged from $41 \%$ to $49 \%$ and temperature from $27.1^{\circ} \mathrm{C}$

Table 1: Population dynamics of wheat aphids.

\begin{tabular}{lc}
\hline Dates of observation & Aphid population 1 plant \\
\hline $02 / 02 / 2019$ & 0.00 \\
$12 / 02 / 2019$ & 1.82 \\
$22 / 02 / 2019$ & 3.00 \\
$04 / 03 / 2019$ & 8.77 \\
$14 / 03 / 2019$ & 14.35 \\
$22 / 03 / 2019$ & 11.25 \\
$03 / 04 / 2019$ & 2.96 \\
\hline
\end{tabular}

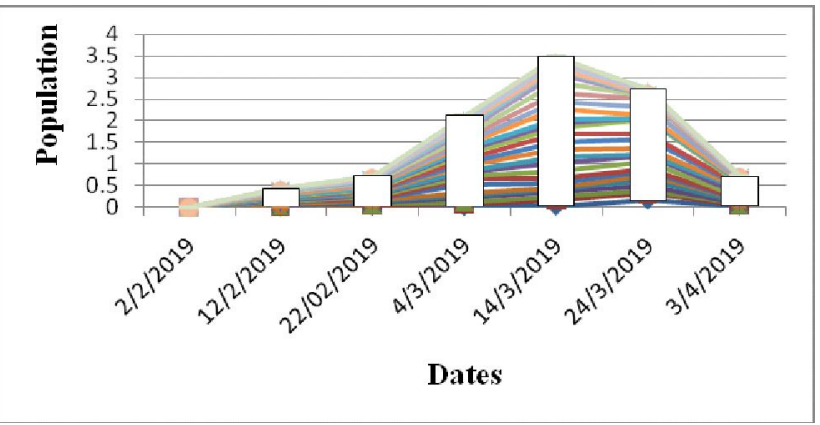

Fig 1: The effect of weather parameters on the population dynamics of wheat aphids. 
to $11.9^{\circ} \mathrm{C}$ being highest and lowest respectively. $\mathrm{RH}$ attained $50 \%$ and aphid population lowered down to 2.96 aphids/plant while at the end no counts were seen in the field (Fig 1).

\section{Yield loss estimation}

The results showed that the yield per plot ranged between $189.40 \mathrm{gm}$ to $1015.00 \mathrm{gm}$ with an average of $695.00 \mathrm{gm}$ in treated plots as compared to $10.00 \mathrm{gm}$ to $15.6 \mathrm{gm}$ with an average of $12.67 \mathrm{gm}$ in untreated plots (Table 2). $21.37 \%$ further yield was recorded in plots treated with Malamar $50 \%$ EC (W/V). On the other hand, the statistical analysis shows that the means varied significantly between treatments.

The 1000-grain weight per plot ranged from 24.50 to 40.40 with an average of $29.89 \mathrm{gm}$ (Table 3 ) in treated plots as compared to 10.00 to 15.60 with an average of $13.50 \mathrm{gm}$ in untreated plots, $10.60 \%$ boost happened in 1000-grain weight in the plot where insecticide was sprayed (Table 2)

An infestation of Russian wheat aphids occurred in the 2nd week of February on the foliage and slowly augmented throughout the vegetative growth of the wheat crop. Khan et al. (2011), reported that wheat crop yield victims caused by the aphids invasion at dry Zone Research Institute (AZRI), Bhakkar, Pakistan through 2004-05. The population reached its peak in the 3rd week of March throughout the heading stage of the wheat and gradually declined till the crop reached maturity with 2.96 aphids/plant in April. Similar results were shown by Karimullah and Ahmad (1989); who observed that aphids' infestation started in the $2^{\text {nd }}$ week of February and peaked in the latter $2^{\text {nd }}$ week of March with fluctuations in population size thereafter up to the beginning of April. Our results are in conformity to Azhar et al. (2011) who observed that effect of wheat cultivars on aphids and their predator populations; and Nawaz, (2000); the population of aphids in the field increased with the development of the wheat and peaked at the heading stage. Graphical presentation (Fig 1) shows that the aphid infestation started in the $2^{\text {nd }}$ week of February up to the end of March, the increase in the population remained very slow, where temperature range was $10.2^{\circ} \mathrm{C}-19.5^{\circ} \mathrm{C}$ and the $\mathrm{RH}$ ranged $30 \%-49 \%$. At the beginning of the $2^{\text {nd }}$ week of March, the slow boost in temperature occurred and a pointed increase in population was recorded up to the mid of March. The temperature in which the population increased was in the range of $11.6^{\circ} \mathrm{C}-27.5^{\circ} \mathrm{C}$ and $\mathrm{RH} 64-75 \%$ was recorded. After the mid of March, the temperature and $\mathrm{RH}$ again increased but a pointed reduction in the aphid population was recorded. After the $1^{\text {st }}$ week of April, no aphids were observed in the field.

Our finding arein parity with Yang, (1990); who reported that at low temperature, the developmental stage was late, while high temperatures reduce the reproductive ability and he besides done that a temperature of $25^{\circ} \mathrm{C}$ is favorable for population growth. In the present experiment, the maximum population was recorded on $14^{\text {th }}$ March that was 14.35 aphids/plant at $19.5^{\circ} \mathrm{C}$. likewise, Kostyukovskii and Kushneuk (1990); see that the number of aphids increased at $15-18^{\circ} \mathrm{C}$ during the earring and flowering of wheat. The maximum population concentration was recorded for the period of heading and grain development. The turn down in the aphid population could moreover be the result of the crop maturity as stated by Riedell, (1990); that invasion of aphids on the wheat crop is abundant for the duration of the heading and flowering phases and is declined for the period of the maturity point of the crop. In finding, a decrease of $15.60 \%$ in the yield and $10.00 \%$ in the thousand-grain weight

Table 2: Yield losses assessment due to aphid infestation in wheat.

\begin{tabular}{|c|c|c|c|c|c|c|}
\hline \multirow[t]{2}{*}{ Yield losses estimation (gm/plot) } & \multirow{2}{*}{$\begin{array}{l}\text { Treatments } \\
\text { Unsprayed }\end{array}$} & \multicolumn{2}{|c|}{ Range } & \multirow{2}{*}{$\frac{\text { Mean }}{161.67^{\mathrm{e}}}$} & \multirow{2}{*}{$\begin{array}{l}\text { CV\% } \\
20.25\end{array}$} & \multirow{2}{*}{$\frac{\text { LSD }}{158.2}$} \\
\hline & & 15.6 & 205 & & & \\
\hline & Neem seed & 33.8 & 330 & $285.00^{\text {de }}$ & & \\
\hline & M. anisopliae & 30.9 & 335 & $296.67^{\text {de }}$ & & \\
\hline & B. bassiana & 30.8 & 455 & $366.67^{c d}$ & & \\
\hline & Neem leaf & 32.8 & 455 & $381.67^{\mathrm{cd}}$ & & \\
\hline & B. bassiana $+M$. anisopliae & 32 & 545 & $461.67^{c}$ & & \\
\hline & Neem Leaf + Neem seed & 28 & 525 & $491.67^{c}$ & & \\
\hline & Dimeto $40 \%$ EC & 33.4 & 890 & $703.33^{b}$ & & \\
\hline & Malamar $50 \%$ EC (W/V) & 40 & 1055 & $913.33^{a}$ & & \\
\hline \multirow[t]{9}{*}{ Thousand Grain Weight } & Untreated & 10 & 15.6 & $12.667^{d}$ & 10.80 & 5.59 \\
\hline & Neem seed & 20.3 & 33.8 & $28.467^{c}$ & & \\
\hline & M.anisopliae & 24.5 & 32.8 & $28.833^{\mathrm{bc}}$ & & \\
\hline & B. bassiana & 27.8 & 30.8 & $28.967^{c}$ & & \\
\hline & Neem leaf & 28 & 31.1 & $29.433^{c}$ & & \\
\hline & B. bassiana $+M$. anisopliae & 30.1 & 31 & $31.667^{\mathrm{ab}}$ & & \\
\hline & Neem Leaf + Neem seed & 32 & 34.3 & $35.100^{c}$ & & \\
\hline & Dimeto $40 \%$ EC & 33.4 & 38.6 & $36.300^{\mathrm{ab}}$ & & \\
\hline & Malamar $50 \%$ EC (W/V) & 32.2 & 40.4 & $37.533^{a}$ & & \\
\hline
\end{tabular}

$\mathrm{P} \leq 0.05 ; \mathrm{T} 1-\mathrm{T} 8$ = Sprayed; T9 $=$ Unsprayed. 
Yield Reductions of Wheat Cultivar Obora (UTIQUE96/FLAG-1) due to Russian Wheat Aphid (Diuraphis noxia) Infestation...

Table 3: ANOVA for yield (1000-grain weight).

\begin{tabular}{|c|c|c|c|c|c|c|c|c|c|c|}
\hline \multirow{2}{*}{ Source of variation } & \multicolumn{5}{|c|}{ Yield loss assessment (gm/plot) } & \multicolumn{5}{|c|}{ 1000-grain weight comparison } \\
\hline & DF & SS & MS & F-Value & $\mathrm{PR}>\mathrm{F}$ & DF & SS & MS & F-Value & $P R>F$ \\
\hline Replication & 3 & 1330120.37 & 133012.04 & 15.92 & $<.0001$ & 16 & 1356.319 & 135.63 & 13.02 & $<.0001$ \\
\hline Treatments & 9 & & 8353.704 & & & & & 10.42 & & \\
\hline Error & 27 & 133659.26 & & & & 27 & 166.655 & & & \\
\hline Corrected total & 26 & 1463779.63 & & & & 26 & 1522.974 & & & \\
\hline R-Square & \multicolumn{2}{|c|}{$C V(\%)$} & RMSE & LSD & Mean & R-Square & CV (\%) & RMSE & LSD & Mean \\
\hline 0.908689 & \multicolumn{2}{|c|}{20.25} & 91.39 & 158.2 & 451.29 & 0.89 & 10.799 & 3.23 & 5.59 & 29.89 \\
\hline
\end{tabular}

was recorded due to aphid infestation (Table 3). Here, our results are in parity with (Miller and Haile,1988) who observed a reduction in yield as $70 \%$ in wheat in Ethiopia and Khan, (2000); while Gair et al. (1987); and Oakley et al. (1993); observed a decrease in yield and thousand-grain weight as $39 \%$ and $12 \%$ respectively which are more as in our schoolwork.

\section{CONCLUSION}

In accordance to our findings, it is accomplished that before maturity, wheat cultivar Obora (UTIQUE96/FLAG-1) were the most susceptible to aphid infestation under the field conditions. Optimum temperature and relative humidity, as well as plant growth conditions for the development of Diuraphis noxia (RWA), survived in wheat. Total susceptible fruitful plants infested with RWA were observed in wheatcultivar Obora (UTIQUE96/FLAG-1). However, the variety of Obora (UTIQUE96/FLAG-1) was most preferred during the vegetative and flowering stages. Moreover, the $2^{\text {nd }}$ week of March was verified as the most critical period for the maximum aphid infestation on the wheat crop, starting from February and continued till the $1^{\text {st }}$ week of April under field conditions. The yield losses of yield and 1000-grain weight were estimated in Obora (UTIQUE96/FLAG-1) infested with RWA was, $15.60 \%$ and $10.00 \%$, respectively.

\section{REFERENCES}

Aheer, G.M., Munir, M., Ali, A. (2007). Impact of weather factors on the population of wheat aphids at Mandi Baha-ud-Din district. Journal of Agricultural Research. 45: 61-66.

Aheer, G.M., Ali, A., Ahmad, M. (2008). Abiotic factors affect population fluctuation of a late aphids in wheat. Journal of Agricultural Research. 46: 367-371.

Alemu, A., Getnet, M. (2012). Yield loss assessment in bread wheat varieties caused by yellow rust (Puccinia striformis $\mathrm{f}$. sp. tritici) in Arsi Highlands of South Eastern Ethiopia. American Journal of Bioscience. pp. 104-112. doi: 10.11648/j.ajbio. 20190706.14.

Anna-Maria, B., Youchun, L. and Lapitan, N.L.V. (2003). Cereal host interactions with Russian wheat aphid: A review. Journal of Plant Interactions. 1(4): 211-222.

Aslam, M., Razaq, M., Akhter, W., Faheem, M., Ahmad, F. (2005). Effect of sowing date of wheat on aphid (Schizaphis gramium RONDANI) population. Pak Entomol. 27: 79-82.
ATA, (2014.) Agricultural Transformation Agency.

Azhar, A.K., Khan, A.M., Tahir, H.M., Afzal, M., Khaliq, A., Khan, S.Y. and Raza, I. (2011). Effect of wheat cultivars on aphids and their predator populations. African Journal of Biotechnology. 10(80): 18399-18402.

Burnett, P.A., Robinson, J., Skovmand, B., Mujeeb-Kazi, A. and Hettel, G. (1991). Russian Wheat Aphid Research at CIMMYT. Current Status and Future Goals. Wheat Special Report No. 1. Mexico, D.F.: CIMMYT.

CSA (Central Statistical Agency), (2014). Agricultural sample survey report on area and production of major crops. Statistical Bulletin (532), Volume VI, Addis Ababa, Ethiopia.

Demeke, M. and Di Marcantonio, F. (2013). Analysis of incentives and disincentives for wheat in Ethiopia. Technical notes series, MAFAP, FAO and Rome.

Falola, A., Achem, B.A., Oloyede, W.O. and Olawuyi, G.O., (2017). Determinants of Commercial Production of Wheat in Nigeria: A Case Study of Bakura Local Government Area, Zamfara State. Trakia Journal of Sciences. 15(4): 397-404.

FAO, (2009). Agricultural commodities: profiles and relevant WTO negotiating issues, 2009. Retrieved fromhttp://www.fao. org/docrep/006/y4343e/y4343e02.htm\#TopOfPage)

Gair, R., Jenkins, J.E.E., Lester, E. (1987). Cereal pests and diseases ( (th $^{\text {th }}$ edn). Farming Press Ltd, United Kingdom.

Haregewoin, T., Belay, B., Bezabeh, E., Kelemu, K., Hailu, D. and Daniel, F., (2018). Impact of Improved Wheat Variety on Productivity in Oromia Regional State, Ethiopia.

Karimullah, Ahmad, K.F. (1989). Incidence of the cereal aphid Sitobion avenae $(F)$ on different cultivars of wheat. Sarhad Journal of Agriculture. 5: 59-61.

Hatchett, A.H., Starks, K.J., Webster, J.A. (1987). Insect and mites pest of wheat: In Wheat and wheat improvement (E.G. Heyne Edition) Madison, Wisconsin, USA.

Khan, A.A., Khan, A.M., Tahir, H.M., Afzal, M., Khaliq, A. et al. (2011). Effect of wheat cultivars on aphids and their predator populations. African Journal of Biotechnology. 10: 18399-18402.

Khan, S.S. (2000). Impact of plant phenology of various wheat genotypes on aphid population and subsequent losses in wheat due to aphids. Approved M.Sc. Thesis, Dept of Plant Protection, NWFP Agricultural University, Peshawar.

Khakwani, A.A., Dennett, M.D., Munir, M. and Abid, M. (2012). Growth and yield response of wheat varieties to water stress at booting and an thesis stages of development. Pakistan Journal of Botany. 44: 879-886.

Kiss, J. (2011). Some impacts of the EU accession on the New Member States' agriculture. Eastern Journal of European Studies. 2(2): 49-60. 
Kostyukovskii, M.G., Kushnerik, V.M. (1990). Population dynamics of cereal leaf aphids on winter wheat. Zashchita Rastenii (Kiev). 37: 10-13.

Miller, R.H. and Haile, A. (1988). Russian wheat aphid on barley in Ethiopia. Rachis. 7: 51.

Najafi, A. (2014). Wheat production price-performance prediction in the Iranian north province. African Journal of Agricultural Research. 9(1): 74- 79.

Nawaz, H. (2000). Insect pest of wheat and the effect of fertilizer (NPK) on aphid population. M.Sc Thesis Deptt of Entomology, NWFP Agricultural University, Peshawar.

Nigussie, A., Kedir, A., Adisu, A., Belay, G., Gebrie, D. and Desalegn, K. (2015). Bread wheat production in small scale irrigation users agro-pastoral households in Ethiopia: Case of Afar and Oromia Regional State. Journal of Development and Agricultural Economics. 7(4): 123-130.
Oakley, U.N., Ellis, S.A., Walters, K.F.A., Watling M (1993). The effects of cereal aphid feeding on wheat quality: Cereal Quality III, proceedings of Association of Applied Biologist, Churchill College Cambridge, UK Aspects of Applied Biology.

Riedell, W.E. (1990). Tolerance of wheat to Russian Wheat aphids: Nitrogen fertilization reduces yield loss. Journal of Plant Nutrition. 13: 579-584.

Sultan, U. (2016). Analysis of Wheat Value Chain: The case of Sinan district, Bale Zone, Oromia region, Ethiopia. Thesis Haramaya University, Haramaya, Ethiopia.

Wains, M.S., Aziz-ur-Rehman, Latif, M., Hussain, M. (2008). Aphid dynamics in wheat as affected by weather and crop planting time. Journal of Agricultural Research. 46: 361-366.

Yang, X.W. (1990). Effects of temperature and light on the population growth of Schizaphis graminum (Rondani). Insect Knowledge. 27: 263-266. 